\author{
Suyanto ${ }^{1}$ \\ ${ }^{1}$ Fakultas IImu Keperawatan, Universitas Islam Sultan Agung Semarang
}

\begin{abstract}
ABSTRAK
Penderita neuropati perifer diabetik yang mengalami penurunan sensasi kaki dapat berakibat terjadinya luka diabetik. Penelitian ini bertujuan mengetahui efektivitas kombinasi senam kaki diabetik dan terapi SPA terhadap peningkatan sensasi kaki pada pasien dengan neuropati perifer diabetik. Penelitian ini menggunakan kuasi experimental pretest-posttest design without control group dengan jumlah sample 17 orang yang didapat dengan tehnik purposive sampling. Pengukuran sensasi kaki dilakukan pada hari pertama minggu ke-1 dan hari terakhir minggu ke-4 perlakuan. Sampel penelitian yaitu pasien neuropati perifer diabetik dengan skor sensasi kaki maksimal 8. Hasil uji wilcoxon menunjukkan ada perbedaan rerata peningkatan sensasi kaki yang diberikan kombinasi senam kaki diabetik dan terapi SPA dibandingkan hanya diberikan tindakan senam kaki diabetik ( $p$ value $<0.05$ ). Tindakan kombinasi senam kaki diabetik dan terapi SPA lebih efektif dalam meningkatkan sensasi kaki yang akan berpengaruh terhadap menurunnya resiko luka pada pasien DM
\end{abstract}

Kata kunci: Diabetes melitus, neuropati perifer diabetik, senam kaki diabetik, terapi SPA

THE INFLUENCE OF SPA THERAPY AND DIABETIC FOOT EXERCISE ON DIABETIC PERIPHERAL

\title{
NEUROPATHY PATIENTS
}

\section{ABSTRACT}

Diabetic peripheral neuropathy patients with decreasing in foot sensation will impact on diabetic ulcers. This study aims to explore the effect of combination between diabetic legs exercise and SPA therapy on foot sensitivity escalation among patients with diabetic peripheral neuropathy. This study used quasi-experimental pretest-posttest design without control group with 17 respondents and recruited by purposive sampling methode. Data were collected from patients with peripheral diabetic neuropathy and had 8 maximum score of foot sensitivity.. Foot sensitivity was measured on the $1^{\text {st }}$ day of intervention and end day of intervention. Wilcoxon test analysis showed significant differences on foot sensitivity with combination of diabetic legs exercise and SPA therapy compare to diabetic legs exercise only ( $p$ value $<0.05$ ). It can be inferred that combination of diabetic legs exercise and SPA therapy are more effective to increase legs sensitivity. Therefore, combined effect of those therapies may eventually decrease diabetic ulcers risk.

Keyword: Diabetic mellitus, diabetic peripheral neuropathy, legs exercise, SPA therapy

Corresponding Author : 
Suyanto $^{1}$, Fakultas IImu Keperawatan Universitas Islam Sultan Agung Semarang. E-mail : suyanto@unissula.ac.id

\section{PENDAHULUAN}

Diabetes melitus (DM) merupakan salah satu penyakit kronik yang terjadi di seluruh negara di dunia, dan terus menerus mengalami peningkatan jumlah menjadi makrovaskular (penyakit jantung koroner, stroke) dan mikrovaskular (retinopati, nefropati, neuropati) (Black \& Hawk, 2009). Komplikasi mikrovaskular meliputi kerusakan pada mata (retinopati) yang menyebabkan kebutaan, kerusakan pada ginjal (nefropati) yang berakhir pada gagal ginjal, dan juga kerusakan pada syaraf (neuropati) yang berakibat pada gangguan kaki diabetes sampai kemungkinan terjadinya amputasi pada tungkai (Ignatavicius \& Workman, 2010).

Insidensi neuropati diabetik terjadi antara 60\% sampai 70\% pada pasien DM tipe I dan tipe II dengan adanya komplikasi neurologi (Lemone \& Burke, 2008). Neuropati perifer diabetik akan menimbulkan gejala umum, meliputi : parastesia distal, nyeri seperti kesakitan/ terbakar, atau seperti tertusuk, dan kaki terasa dingin. Manifestasi lain meliputi: berkurangnya sensasi proteksi; nyeri, suhu, sentuhan getaran (Kohnle, 2008).

Berkurangnya sensasi proteksi menyebabkan pasien DM berisiko mengalami injuri pada daerah perifer khususnya kaki. Doctherman \& Bulechek (2004) menyatakan bahwa intervensi keperawatan untuk pasien yang mengalami penurunan sensasi di kaki antara lain manajemen sensasi perifer dan perawatan kaki. Bentuk perawatan kaki antara lain adalah senam kaki dan menggunakan air hangat. National Diabetes Information Clearinghouse (2005) menyatakan bahwa salah satu tindakan dalam perawatan kaki pasien dengan neuropati perifer diabetik adalah dengan membersihkan kaki dengan menggunakan air hangat.

Senam kaki diabetik merupakan kegiatan atau latihan dengan intensitas sedang yang dilakukan oleh pasien DM untuk mencegah terjadinya luka dan membantu melancarkan peredaran darah bagian kaki (Suriadi, 2004). Latihan intensitas sedang dapat menyebabkan pemulihan fungsi saraf perifer dengan menghambat reduktase aldosa (AR) yang mengarah ke menurunnya NADPH (Nicotinamide Adenine Dinucleotide Fosfat Hidroksida). Penurunan NADPH dapat berkontribusi dalam meningkatkan sintesis nitrat oksida (NO) yang akan menghilangkan hipoksia pada saraf. Peningkatan endotel berasal nitrat oksida (NO) juga dapat menyebabkan pemulihan fungsi saraf pada pasien DPN. 
Tindakan senam kaki diabetik dapat meningkatkan nitrat oksida dan penghambatan produksi berlebihan protein kinase $\mathrm{C}$.

Terapi SPA dapat meningkatkan metabolisme glutation. Otsuka (1996) dalam Nasermoaddeli \& Kagamimori, (2005) menyatakan bahwa dari uji coba terkontrol klinis pada 12 pasien DM tipe II di Hokkaido yang dilakukan terapi SPA selama dua atau tiga kali sehari dalam empat minggu dengan suhu air antara 39 sampai 40 derajat celcius (tidak ada data tentang komposisi mineral), didapatkan hasil bahwa sebagian ada perbaikan metabolisme glutation.

Glutation merupakan antioksidan sel untuk mencegah kerusakan oksidatif (Nuttal et al., 1999). Kombinasi dari kedua tindakan tersebut diharapkan akan mempercepat pengurangan neuropati perifer diabetik terutama peningkatan sensasi kaki. Penelitian ini bertujuan untuk mengetahui efektivitas kombinasi senam kaki diabetik dan terapi SPA terhadap peningkatan sensasi kaki pasien neuropati perifer diabetik.

\section{METODE}

Desain penelitian quasi eksperimen dengan teknik pretest posttest without control group design. Tiga puluh delapan pasien neuropati perifer diabetik ikut serta dalam penelitian ini yang dipilih secara purposive sampling. Instrumen yang digunakan untuk mengukur sensasi kaki yakni Siemens Weinstein Monofilament 10.

Prosedur pengambilan data dilakukan selama 4 minggu. Hari pertama pada minggu pertama, baik kelompok kontrol dan intervensi diukur skor pretest untuk menilai skor sensasi kaki. Kemudian dilakukan tindakan kombinasi senam kaki dan terapi SPA untuk kelompok intervensi, serta dilakukan tindakan senam kaki diabetik untuk kelompok kontrol. Tindakan dilakukan per dua hari. Pengukuran posttest dilakukan pada hari terakhir minggu ke 4 untuk menilai skor sensasi setelah dilakukan perlakuan baik pada kelompok kontrol dan intervensi. Data yang telah terkumpul kemudian diolah dengan menggunakan program komputer. Adapun etika pengambilan data memegang prinsip self determinant privacy, anonimity, confidentiality confidentiality, dan justice.

\section{HASIL}

Analisis pada variabel-variabel di dalam penelitian ini dilakukan secara univariat, bivariat. Analisis univariat digunakan untuk mendeskripsikan hasil penelitian dari masing-masing variabel yang diteliti. Analisis bivariat digunakan untuk mengetahui hubungan antara variabel terikat dan variabel bebas. 
Karakteristik responden terdiri dari usia jenis kelamin, lama menderita DM, terapi farmakologi, dan ABI. Rerata umur responden adalah $49.5(95 \% \mathrm{Cl})$ dengan standar deviasi 6.7. Jenis kelamin kedua kelompok dalam penelitian ini sebagian besar perempuan ( $\geq 68.4 \%)$. Rerata lama menderita DM 4.6 tahun $(95 \% \mathrm{Cl})$ dengan standar deviasi 2. Rerata nilai $\mathrm{ABI}$ pada kelompok intervensi adalah 0.85 (95\% $\mathrm{Cl})$ dengan standar deviasi 0.05 . Sebagian besar responden kedua kelompok mengkonsumsi obat hipoglikemik oral $(\mathrm{OHO})$ sebesar $\geq 84.1 \%$.

Skor sensasi kaki pasien kelompok intervensi sebelum perlakuan rata-rata pada skor 6.84 dengan nilai minimal adalah 5 dan nilai maksimum adalah 8. Skor sensasi kaki pasien kelompok rata-rata pada skor 8.68 dengan nilai minimum 8 dan nilai maksimum 9. Hal ini menunjukkan selisih antara sebelum dan setelah perlakuan pada kelompok intervensi adalah 2. Hasil uji wilcoxon pada kelompok intervensi terdapat perbedaan yang signifikan nilai rerata skor sensasi kaki sebelum dan setelah perlakuan $(p=0,001 ; \alpha=0,05)$.

\section{PEMBAHASAN}

Rata-rata responden dalam penelitian ini termasuk kedalam klasifikasi lansia tengah dengan rentang umur 45 - 65 tahun. DM tiep 2 yang berumur kurang dari 70 tahun memiliki resiko lebih tinggi mengalami komplikasi mikrovaskuler seperti neuropati, retinopati, dan nefropati ( Floch, Doucet, Bauduceu, \& Verny., 2013). Hasil penelitian ini tidak sesuai dengan penelitian sebelumnya yang menyatakan bahwa rata-rata usia penderita DM yang mengalami neuropati yakni berumur 55.1 tahun (Booya, et al. 2005).

Jenis kelamin yang dominan pada penelitian ini adalah perempuan. Hal ini tidak sesuai dengan pendapat bahwa laki-laki beresiko 2 kali lebih besar mengalami luka kaki dibandingkan wanita. hal ini dikarenakan laki-laki lebih banyak merokok dan minum alkohol sehingga dapat merusak syaraf (National diabetes information clearinghouse, 2002). Penelitian relevan lainnya menyatakan bahwa perbedaan gender merupakan salah satu faktor yang berpengaruh terhadap kejadian neuropati, alasan ilmiah yang mendasari perbedaan tersebut masih menjadi perdebatan dan diperlukan penelitian lebih lanjut (Kodali, Seshaiah, \& Kumar, 1990). Menurut asumsi peneliti karena terbatasnya jumlah responden dan area penelitian yang hanya melibatkan satu rumah sakit, maka hal tersebut belum dapat menggambarkan proporsi mayoritas mengenai jenis kelamin yang mengalami neuropati perifer diabetik. 
Rata - rata lama menderita DM pada kelompok intervensi adalah 4.6 tahun. Sedangkan distribusi rata - rata lama menderita DM pada kelompok kontrol lebih pendek yaitu 4.4 tahun. Hasil ini sesuai dengan penelitian relevan lainnya yang menyatakan bahwa neuropati perifer diabetik yang dialami pasien DM terjadi sejak 3 - 5 tahun setelah terdiagnosa DM (Tefaye et al, 2005). Lama waktu mengalami DM seiring dengan komplikasi, dalam arti semakin lama mengalami DM maka semakin tinggi pula kejadian komplikasi yang dialami oleh pasien (Hermanns, Mahr, Kulzer, Skovlund, \& Haak, 2010).

Menurut Suzuki, et al (2001) menyatakan bahwa lamanya menderita DM dengan hiperglikemi mempengaruhi perubahan terhadap dinding pembuluh darah dan tekanan darah. Lama waktu terdiagnosa DM juga berkaitan dengan penurunan fungsi sel beta pankreas sehingga menimbulkan komplikasi yang secara umum terjadi pada pasien dengan lama sakit 5 - 10 tahun (Smeltzer \& Bare, 2010). Hal ini sesuai dengan teori yang menyatakan bahwa penurunan fungsi sel beta pankreas akan berdampak pada berkurangnya jumlah produksi insulin didalam darah akan menurunkan proses glikolisis didalam sel. Akibatnya glukosa yang tidak terserap oleh sel akan menyebabkan peningkatan akumulasi glukosa pada pembuluh darah dan menjadikan kondisi hiperglikemik (Guyton, 2007).

Hasil penelitian ini didapatkan hasil bahwa sebagian besar responden baik kelompok kontrol dan kelompok intervensi mengkonsumsi obat antihiperglikemik oral (OHO). Jenis $\mathrm{OHO}$ yang sering dikonsumsi responden adalah Metformin dalam jangka waktu minimal 1 tahun. Hasil penelitian yang relevan menyatakan bahwa bahwa pasien dengan neuropati perifer diabetik tipe II, dan mengkonsumsi metformin lebih dari 6 bulan memiliki serum rendah Vitamin B12 (Cobalamin/Cbl) dan tanda menunjukkan klinis neuropati perifer yang lebih parah dibandingkan dengan pasien yang tidak terpapar metformin (Wile \& Toth, 2010).

Vitamin B12 (cobalamin) berfungi untuk membantu menjaga sel-sel saraf yang sehat dan sel darah merah. Hal ini juga diperlukan untuk membuat bahan genetik dalam semua sel. Vitamin B12 juga disebut cobalamin karena mengandung kobalt logam. Vitamin B12 terikat dengan protein dalam makanan. Asam klorida dalam lambung melepaskan B12 dari makanan selama proses pencernaan, dimana ia kemudian menggabungkan dengan zat yang disebut intrinsik faktor dan dapat diserap dalam usus kecil. Salah satu tanda dan gejala defisiensi B12 adalah mati rasa dan kesemutan di tangan dan kaki (Gilligan, 2002).

Hasil penelitian ini menunjukkan bahwa sirkulasi tubuh mengalami penurunan pada level yang ringan. Hal tersebut sesuai dengan Crique et al (2005) yang menemukan bahwa nilai ABI pada 
penderita neuropati diabetik relatif tidak normal. Aliran darah yang buruk merupakan masalah utama pada responden DM. Hal ini menyebabkan lambatnya proses penyembuhan luka, peningkatan resiko infeksi dan amputasi (Farmet, et al, 2005). Salah satu faktor yang berpengaruh terhadap nilai $\mathrm{ABI}$ adalah riwayat konsumsi merokok (Polenova, 2009). Hasil penelitian lain juga bahwa riwayat atau merokok mempengaruhi pembuluh darah karena menyebabkan aterosklerosis dalam pembuluh darah. Akibat dari atersoklerosis tersebut akan meningkatkan tekanan sistolik yang akan berkontribusi besar terhadap nilai ABI (Jung, Chu, Bhan, 2011). Salah satu tanda penderita neuropati perifer diabetik adalah adanya mati rasa pada telapak kaki yang disebabkan gangguan sistem syaraf perifer yang sangat erat hubungannya dengan dampak hiperglikemik kronik dan faktor neurovaskuler yang menyebabkan kerusakan pembuluh darah yang membawa oksigen dan nutrisi ke syaraf (National diabetes information clearinghouse, 2002). Disfungsi syaraf perifer pada penderita neuropati diabetik perifer menyebabkan terjadinya penurunan sensasi kaki (Sakowski \& Feldman, 2012).

Hasil penelitian yang relevan menyatakan bahwa latihan ringan termasuk senam kaki diabetik dapat meningkatkan pelebaran mikrovaskular, mengurangi stres oksidatif (Hennigan, O'Callaghan,\& Kelly, 2007). Penelitian yang relevan juga menyatakan bahwa senam kaki dapat menyebabkan pemulihan fungsi syaraf perifer dengan menghambat reduktase aldosa yang mengarah ke menurunnya NADPH yang akan meningkatkan aktifitas sel endotel (Hutchinson et al, 2000).

Prosedur tindakan terapi SPA yang dilakukan dalam penelitian ini adalah dengan melakukan kombinasi perendaman air dengan suhu $38^{\circ} \mathrm{C}$ sampai $40^{\circ} \mathrm{C}$ dan massase. Menurut Ignatavicius \& Blach (2006) bahwa vasodilatasi pembuluh darah dapat dicapai dengan mempertahankan pembuluh darah tetap hangat, menghindari kondisi ding 'ı, mengurangi stres emosional serta mencegah terjadinya vasokintriksi. Hasil penelitian yang sama juga menjelaskan bahwa rendam kaki menggunakan air hangat dapat mengakibatkan vasodilatasi darah dan melebar lumen arteri sehingga menurunkan resistensi aliran darah yang akan meningkatkan aliran darah (Chandramolesswaran \& Govardhan, 2011). Penelitian yang senada menyatakan rendam air hangat dapat menurunkan terjadinya terjadinya aterosklerosis. Hasil penelitian yang relevan menjelaskan bahwa perendaman air hangat pada seluruh tubuh dapat meningkatkan serum adiponektin dan leptin pada orang sehat (Shimodozono et al., 2011). Hasil penelitian lainnya bahwa terapi SPA dapat meningkatkan serum leptin dan tingkat adiponektin pada penderita osteoarthritis (Fiovaranti et al., 2010). Adiponektin dan leptin merupakan adipoksit-deriverat hormon yang berperan penting antara obesitas dan gangguan inflamasi (Peterlin, 2009). Adiponektin mengurangi baik produksi dan aktivitas sitokin inflamasi dan 
membantu melindungi terhadap obesitas, peradangan pembuluh darah dan perkembangan aterosklerosis (Rondinone, 2006).

Tindakan kombinasi senam kaki diabetik dan terapi SPA memiliki tujuan yang sama yakni meningkatkan sirkuasi darah. Hasil penelitian ini senada dengan penelitian sebelumnya yang menyatakan bahwa pasien DM dengan neuropati yang dilakukan perawatan kaki dengan menjaga sirkulasi darah kaki dihasilkan kelompok yang tidak melakukan perawatan kaki 13 kali berisiko terjadi ulkus diabetika dibandingkan kelompok yang melakukan perawatan kaki secara teratur (Calle, Pascual, \& Duran, 2001).

Tahapan pelaksanaan terapi SPA setelah dilakukan perendaman air hangat adalah dilakukan massase pada kaki. Prosedur massase dapat memperbaiki sirkulasi darah dan limfe, dengan cara meningkatkan hantaran oksigen dan zat makanan ke dalam sel tubuh, sekaligus juga meningkatkan pengeluaran sampah metabolisme dari tubuh (Tappan \& Benjamin, 1998). Hasil penelitian yang relevan menyebutkan bahwa 56\% responden berespon baik (gejala neuropati diabetik menghilang) setelah dilakukan masase (Jeanette et al, 2001).

\section{SIMPULAN DAN SARAN}

\section{Simpulan}

Terdapat perbedaan yang signifikan sensasi kaki antara pemberian kombinasi senam kaki diabetik dan terapi SPA dengan pemberian senam kaki diabetikk. Terdapat perbedaan yang signifikan sensasi kaki sebelum dan sesudah perlakuan pada masing-masing kelompok.

\section{Saran}

Perlu dilakukan penelitian lainnya mengenai efek dari kombinasi terapi SPA dan senam kaki terhadap nilai Ankle Brakhial Indext pasien diabetes mellitus.

\section{KEPUSTAKAAN}

Booya, F., Bandarian, F., Larijani, B., Pajouhi, M., Nooraei, M, \& Lotfi, J. (2005). Potential risk factors for diabetic neuropathy : A case control study. BMC Neurol, 5, 24

Bryant, R., \& Nix, D. (2007). Acute and chronic wound current concept (3 $3^{\text {rd }}$ ed.). St. Louis: Mosby Elsevier

Carrington, A.L., Abbot,C.A., \& Griffiths,J. (2001). Peipheral vascular and nerve function associated with lower limb amputation in people with and without diabetes. Clin Sci, 101, 261-266

Chandramoleeswaran, P., \& Govardhan, K. (2011). Foot care through ayurdeva. International journal of research in ayurdeva \& pharmacy, 24 
Corwin, E. (2009). Hand book of pathophisiolofy. Philadelphia : Mosby

De Meyer,G.R., \& Herman, A.G. (1997). Vascular endothelial dysfunction. Prog Cardiovasc Dis,39,325-342.

Davey, P. (2005). At a glance medicine. Farmet, E.(2005). Diabetic foot ulcer. The journal of american medical association, 293. http://Jama.ama-assn.org/cgi/content/full/293/2:135

Fiovaranti, A., Cantarani, L., Bacarelli, M.R., Lalla, A., Ceccatelli, L., \& Blardi, P. (2010). Effect of spa therapy on serum leptin and adiponectin levels in patients with knee osteoarthritis. Rheumatology international, 31(7), 879-882

Floch, J.P., Doucet, J., Bauduceau, B., \& Verny, C. (2013). Short report: Complications retinopathy, nephropathy, periperal neuropahty and geriatric scale scores in elderly people with type 2 diabetes. Diabetic Medicine, 31, 107-111

Gilligan, M.A. (2002). Metformin and vitamin B12 deficiency. Arch Intern Med, 162, 484- 485

Haller, H. (1997). Endothelial function. General considerations Drugs,53(1),1-10.

Hayat, S.A., Patel,B., Khattar,R.S., \& Malik,R.A. (2004). Diabetic cardiomyopathy: mechanisms, diagnosis and treatment. Clinical Science, 107, 539-557

Hutchinson, A., Mclntosh, A., Feder, R. G., O'Connor, M., Young, R., Clarkson, S., et al. (2000). Clinical guidelines and evidence review for type 2 diabetes: Prevention and management of foot problems. London: Royal College of General Practitioners

Jalwal, M., Leur, A., Bell, R.A., Divers, J., Dabelea, D., Pettitt, D.J.,...et al. (2013). Peripheral neuropathy in adolescents and young adults with type 1 and type 2 diabetes from the search for diabetes in youth follow up cohort. Diabetes care, 36, 3903-3908

Loughlin, D.T, \& Artlett, C.M. (2009). 3-deoxyglucosone-collagen alters human dermal fibroblast migration and adhesion: Implications for impaired wound healing in patients with diabetes. Wound repair and regeneration, 17, 739-749

Nursiswati. (2007). Pengaruh latihan kaki terhadap gejala neuropati perifer pada asuhan keperawatan dengan DM tipe 2 di RSUD Bekasi. Tesis. FIKUI: tidak dipublikasikan

Sakowski, S.A \& Feldman,E.L. (2012). Insulin like growth factors in the peripheral nervous system. Endocrinol metab clin nort, 41 (2), 375-393

Saperstein, D.S., Wolfe, G.I., Gronseth, G.S., Nations, S.P., Herbelin, L.L., Bryan, W.W.,..et al. (2003). Challenges in the identification of cobalamin deficiency polyneuropathy. Arch Neurol, 60, $1296-1301$

Senthil, K.P., Prabha,A., Jeganathan,P.S., D'Souza,S.C., \& Misri,Z.K. (2013). Pathophysiological changes in nerve conduction studies in diabetic peripheral neuropathy: An integrative overview. Indian Journal of Pathology: Research and practice, 2(3), 77-120

Sigal, R.J., Kenny,G.P.,\& Wasserman,D.H (2006). Physical activity/exercise and type 2 diabetes. Diabetes care,29, 1433-1438

Shimodozono, M., Matsumoto, S., Ninomiya, K., Miyata, R., Ogata, A., Etoh, S.,...et al. (2011). Acute effects of a single warm-water bath on serum adiponectin and leptin levels in healthy men : A pilot study. Int J biometeorol, 56, 933-939 
Suzuki, E., Kashigawi, A., Nishio, Y., Egawa, K., Shimizu, S., \& Maegawa, H. (2001). Increased arterial wall stiffness limits flow volume in the lower extremities in type 2 diabetics patients. Diabetic care, 24(12), 2107-2114

Tanaka, Y., Uchino,H., Schimizu,T., Yoshii, H., Niwa,M., Ohmura,C.,...(1999). Effect of metformin on advanced glycation end product formation and peripheral nerve function in streptozotocininduced diabetic rats. Eur J Pharmacol,376, 17-22

Tappan, F.M, \& Benjamin, P.J. (1998). Tappan's handbook healing massase techniques: classic, holistic, and emerging methods ( $3^{\text {rd }}$ ed.). Stamford: Appleton \& Lange

Tesfaye, S. (2006). Diabetic neuropathy. In; Veves A, Giurini JM, LoGerfo FW, editor. The Diabetic Foot, Second Edition. New Jersey: Humaniora Press

Thomsen, K., Rubin, I.,\& Lauritzen, M. (2002). NO and non NO, non prostanoid dependent vasodilatation in rat sciatic nerve during maturation and developing experimental diabetic neuropathy. J Physiol,543, 977-993.

Tkac, I., \& Bril, V. (1998). Glycemic control is related to the electrophysiologic severity of diabetic peripheral sensorimotor polyneuropathy. Diabetes care, 21(10),1749

Tosato, M., Zamboni,V., Femini,A., \& Cesari,M. (2007). The aging process and potentialinterventions to extend life expectancy. Clin Interv Aging, 2 (3), 401-412

Ueno, Y., Kizaki, M., Nakagiri, R., Kamiya, T., Sumi, H.,\& Osawa, T. (2002). Dietary gluthatione protects rats from diabetic nephropathy and neuropathy. J Nutr,132, 897-900.

Urbano, F.(2001). Homans' sign in the diagnosis of deep venous thrombosis. Hosp Physician,1(3), 2224.

Utoyo, B. (2013). Pengaruh massase dan rendam kaki terhadap peningkatan sirkulasi kaki pada pasien diabetes mellitus. Tesis.FIKUI:Tidak dipublikasikan

Xu, D., Li,J., Zou,L., Xu,W., Hu,D., Pagoto,S.L.,...(2010). Sensitivity and specificity of the ankle-brachial indext to diagnose peripheral arteri disease: a structure review. Vascular Medicine,15 (5),361-369

Ziegler, D., Sohr, C.G., Nourooz-Zadeh, J. (2004). Oxidative stress and antioxidant defense in relation to the severity of diabetic polyneuropathy and cardiovascular autonomic neuropathy. Diabetes Care,27, 2178-2183

Zochodne, D.W. (2007). Diabetes mellitus and the peripheral nervous system: manifestations and mechanisms.Muscle nerve, 36 (2), 144-166

Zilliox, L.A., Ruby, S.K., Singh, S., Zhan, M., \& Russel, J.W. (2015). Clinical neuropathy scales in neuropathy associated with impaired glucose tolerance. Journal of diabetes and its complications, 29, 372-377 